\title{
FAKTOR-FAKTOR YANG MEMPENGARUHI KUALITAS INFORMASI PELAYANAN BIDANG AKADEMIK KEPADA MAHASISWA
}

\author{
Sutanto P. Angkoso, Andre N Rahmanto, Yulius Slamet \\ Magister Ilmu Komunikasi Program Pascasarjana Universitas Sebelas Maret
}

\begin{abstract}
ABSTRAK
Penelitian ini bertujuan untuk menganalisis pengaruh akurasi, ketepatan waktu, kelengkapan dan format pada kualitas layanan informasi akademik pada siswa SMA Multimeda Yogyakarta. Populasi penelitian adalah semua siswa yang menerima layanan dalam urusan akademik di Multimedia High School of Yogyakarta. Prosedur sampel adalah Simple Random Sampling yang menghasilkan 106 responden. Metode penelitian adalah penelitian eksplanatori dengan studi publik. Hasil penelitian menunjukkan bahwa keakuratan, ketepatan waktu, kelengkapan dan format memiliki pengaruh yang signifikan terhadap kualitas layanan informasi akademik dengan kontribusi sebesar 38,5\%. Faktor yang paling dominan mempengaruhi kualitas layanan informasi akademik adalah faktor akurasi.

Kata kunci: keakuratan informasi, ketepatan waktu, kelengkapan informasi, format informasi, kualitas layanan informasi akademik
\end{abstract}

\section{ORGANIZATIONAL COMMUNICATION OF EXECUTIVE BOARD EXEMPLARY STUDENTS}

\begin{abstract}
This research aims to analyze the influence of accuracy, timeliness, completeness and format on the quality information services of academic on students of Multimeda High School of Yogyakarta. Research population is all students who receive services in academic affairs in Multimedia High School of Yogyakarta. Sample procedure is Simple Random Sampling producing 106 respondents. The research method is explanatory research with public study. The results show that the accuracy, timeliness, completeness and format have a significant effect on the quality information services of academic with the contribution as much $38.5 \%$. The most dominant factor affecting the quality information services of academic is accuracy factor.

Keywords : accuracy of information, timeliness, completeness of the information, format of information, quality information services of academic
\end{abstract}

Korespondensi: Sutanto Prasetyo Angkoso. Universitas Sebelas Maret. Jl. Ir. Sutami No.36A, Jebres, Kota Surakarta, Jawa Tengah 57126. Email: sutantoangkoso@gmail.com 


\section{PENDAHULUAN}

Pada era saat sekarang ini kebutuhan masyarakat terhadap pendidikan formal semakin meningkat, khususnya pendidikan tinggi, menjadikan perguruan tinggi sebagai sektor strategis yang diharapkan dapat menghasilkan sumber daya manusia yang bermutu. Keadaan persaingan yang cukup kompetitif antar perguruan tinggi menuntut lembaga pendidikan memperhatikan mutu pendidikan dan kelembagaannya sehingga mampu serta unggul dalam persaingan tersebut. Perguruan tinggi harus melakukan langkah antisipasi guna menghadapi persaingan yang semakin kompetitif serta bertanggung jawab untuk menggali dan meningkatkan segala aspek pelayanan yang dimiliki. Pelayanan yang diberikan menurut konsumen itu baik maka sebuah lembaga tersebut dapat menjadi pilihan untuk belajar dalam sebuah lembaga pendidikan. Permasalahan yang dihadapi perguruan tinggi dalam kaitannya dengan pengukuran mutu jasa, penilaian dengan pendekatan akreditasi serta penilaian yang sifatnya langsung seperti tingkat gagal studi (drop out), masa studi dan lainnya diperlukan paradigma baru sebagai indikator pengukuran mutu pendidikan di perguruan tinggi (Sadat, 2000:1).

Mahasiswa merupakan pelanggan atau konsumen bagi institusi pendidikan tinggi.
Lembaga/institusi sudah seharusnya dapat menjamin kepuasan mahasiswa, tidak hanya dalam proses belajar mengajar, tetapi mencakup pula dalam pelayanan administrasinya. Pelayanan administrasi, khususnya pelayanan adminisrasi akademik merupakan hal yang sangat penting dalam menunjang kelancaran studi mereka selama di perguruan tinggi. Meskipun beberapa aspek sudah terkomputerasi dan sudah online, namun pelayanan secara manual tetap diperlukan, sebagai contoh masalah legalisasi, surat menyurat, untuk meningkatkan kualitas informasi (Asih, 2012: 2).

Kualitas Informasi (information quality) pada penelitian Pitter dan Watson dalam DeLone dan McLean (2003) merujuk pada output dari sistem informasi, menyangkut nilai, manfaat, relevansi, dan urgensi dari informasi. Kualitas informasi yang dipersepsikan oleh pengguna, diukur dengan empat indikator penelitian Bailey dan Pearson yaitu keakuratan informasi (accuracy), ketepatwaktuan (timeliness), kelengkapan informasi (completeness) dan penyajian informasi (format).

Permasalahan faktor kualitas sumber daya manusia yang menjalankan sistem informasi, kurangnya pemahaman terhadap sistem aplikasi, lemahnya pengendalian internal, kurangnya komitmen dan dukungan pimpinan satuan kerja, tidak dibentuknya tim atau unit akuntansi 
pelaksana serta beberapa kelemahan lain yang berbeda antar satuan kerja. Hal tersebut dapat berpengaruh terhadap kualitas informasi pelayanan akademik diperguruan tinggi.

Kota Yogyakarta memiliki citra yang cukup terkenal dengan julukan kota pelajar yang terdiri berbagai macam sekolahsekolah maupun perguruan tinggi yang sudah lama berdiri baik perguruan tinggi negeri maupun swasta. Banyaknya perguruan tinggi tersebut salah satunya ada institusi pendidikan kedinasan dibawah Departemen Penerangan dengan nama Multi Media Training Centre yang berdiri sejak tahun 1985, tetapi pada tahun 2002 sudah beralih status menjadi Sekolah Tinggi Multi Media dibawah Kemenkominfo, sampai sekarang telah menyelenggarakan tiga jurusan yaitu Jurusan Penyiaran mempunyai tiga program studi, Jurusan Disain Teknologi Permainan mempunyai dua program studi dan Jurusan Manajemen Informasi Komunikasi (MIK) dengan membuka untuk umum (mahasiswa regular) seperti perguruan tinggi lainnya.

Sekolah Tinggi Multi Media "MMTC" Yogyakarta sebagai lembaga pelayanan pendidikan, terdapat pelimpahan kewenangan pengelolaan pemenuhan jaminan kualitas terhadap mahasiswa kepada masing-masing Jurusan.

Infromasi jejaring media sosial terkait dengan kualitas informasi di Sekolah Tinggi
Multi Media Yogyakarta menunjukkan bahwa manfaat, relevansi, urgensi dan nilai merupakan dimensi yang sangat penting. Akan tetapi informasi tersebut belum akurat, seperti informasi tentang semester pendek tahun ini, mahasiswa tidak mendapatkan informasi yang jelas dan akurat. Mahasiswa berpendapat bahwa keakuratan informasi, ketepatwaktuan, kelengkapan dan format informasi yang disajikan di kampus masih kurang maksimal (Facebook, media sosial STMM-MMTC, 2016). Menurut mereka Informasi kadang sudah dipahami, akan tetapi belum akurat, sistem informasi kurang up to date, sehingga terkadang tidak lengkap. Sistem informasi di STMM juga dinilai monoton sehingga fungsi papan informasi dan jejaring sosial (Facebook group STMM-MMTC) kebanyakan belum dipahami mahasiswa. Selain itu banyak mahasiswa yang mengeluh karena pemberitahuan informasi dengan secara tiba-tiba terutama mengenai batas waktu pembayaran, serta perubahan kuliah, praktik dan tempat ruang kuliah.

Dalam aplikasinya sub bagian akademik bertanggung jawab dengan layanan kegiatan-kegiatan perkuliahan seperti halnya jadwal perkuliahan, nilai, dan kegiatan-kegiatan kemahasiswaan yang berkaitan dengan akademik mahasiswa sampai tingkat wisudawan, sehingga proses yang diharapkan dapat terlaksana dengan baik. Kemudian bidang kemahasiswaan 
bertanggungjawab pada kegiatan-kegiatan mahasiswa yang ada dilingkungan kampus seperti halnya BEM, UKM, Radio dan Televisi Kampus di lingkungan Jurusan Penyiaran, seperti proses pembuatan surat menyurat (legal formal) dalam membuat badan hukum suatu lembaga ekstra dan intra kampus. Dengan tercapainya tugas dan fungsi sub bagian tersebut di atas diharapkan menjadikan pelayanan yang berkulias sehingga bisa mencapai tujuan yang diharapkan dengan melibatkan unsurunsur yang ada.

Permasalahan keakuratan informasi, ketepatwaktuan, kelengkapan dan format informasi yang disajikan hasil (Facebook media sosial group jejaring STMM-MMTC, 2016) dan keluhan mahasiswa tersebut, perlu dilakukan kajian lebih lanjut untuk mengganalisis faktor yang mempengaruhi kualitas pelayanan informasi bidang akademik kepada mahasiswa di Sekolah Tinggi Multi Media Yogyakarta. Penelitian dilakukan secara langsung terhadap mahasiswa yang menggunakan layanan bidang admitrasi periode 2013-2014, sehingga dapat diketahui faktor yang memiliki kontribusi yang kurang dan yang sudah baik sehingga dapat dilakukan perbaikan pada pelayanan akademi sesuai dengan prosedur yang digunakan.

Penelitian ini bertujuan Menganalisa pengaruh keakuratan informasi (Accuracy), ketepatwaktuan (Timeliness), kelengkapann informasi (Completeness) dan penyajian informasi (Format) terhadap kualitas informasi pelayanan Bidang administrasi akademik di Sekolah Tinggi Multi Media Yogyakarta.

Kajian Teori dan Hipotesis Penelitian Suatu Informasi memiliki nilai karena informasi tersebut dapat menjadikan keputusan yang baik serta menguntungkan (memiliki nilai informasi yang tepat). Kualitas informasi yang dipersepsikan oleh pengguna, diukur dengan empat indikator penelitian Bailey dan Pearson yaitu keakuratan informasi (accuracy), ketepatwaktuan (timeliness), kelengkapan informasi (completeness) dan penyajian informasi (format). Kualitas informasi menurut Kadir (2003: 35) diantaranya meliputi keakuratan informasi (accuracy), ketepatwaktuan (timeliness), dan relevan (Relevancy). Sedangkan menurut Amsyah (2001: 316) kualitas informasi yang dipersepsikan oleh pengguna, diukur dengan lima indikator diantaranya Akurasi, Tepat waktu, Relevan, Kelengkapan dan Keringkasan.

Berdasarkan teori dan kajian penelitian sebelumnya, faktor yang mendukung kualitas informasi pelayanan bidang akademik dalam penelitian ini terdiri atas empat faktor yakni keakuratan informasi (accuracy), ketepatwaktuan (timeliness), kelengkapan informasi 
(completeness) dan penyajian informasi (format).

Faktor Keakuratan informasi (accuracy) berpengaruh terhadap kualitas informasi pelayanan bidang akademik

Kualitas informasi pelayanan harus didukung oleh keakuratan informasi yang diberikan. Faktor keakuratan informasi merupakan salah satu hal yang paling penting dalam pelayanan dan penyampaian informasi. Informasi yang diberikan harus bebas dari kesalahan-kesalahan dan tidak biasa atau menyesatkan. Informasi harus jelas mencerminkan maksudnya karena dari sumber informasi sampai ke penerima informasi kemungkinan banyak terjadi gangguan (noise) yang dapat merubah atau merusak informasi tersebut.

Informasi yang akurat dapat berpengaruh pada kualitas informasi dalam pelayanan di bidang akademik. Informasi yang akurat dalam pelayanan akademik harus memiliki kelengkapan yang baik, karena bila informasi yang dihasilkan sebagian tentunya akan memengaruhi dalam pengambilan keputusan atau menentukan tindakan secara keseluruhan, sehingga akan berpengaruh terhadap kemampuannya untuk mengontrol atau memecahkan suatu masalah dengan baik.

Akurasi yang dimaksud dalam penelitian ini adalah tingkat keakuratan dari informasi yang dihasilkan oleh sistem informasi. Ukuran keakuratan informasi bervariasi, dan tergantung pada sifat informasi yang dihasilkan. Semakin kritis sifat suatu informasi, maka semakin tinggi akurasi yang diperlukan. Sehingga semakin tinggi pula kualitas pelayanan yang diberikan yang diberikan kepada penggunanya.

H1: Terdapat pengaruh keakuratan informasi (Accuracy) terhadap kualitas informasi pelayanan Bidang administrasi akademik di Sekolah Tinggi Multi Media Yogyakarta

Faktor Ketepatwaktuan (timeliness) berpengaruh terhadap kualitas informasi pelayanan bidang akademik

Informasi merupakan landasan di dalam pengambilan keputusan. Maka, informasi harus disajikan secara tepat waktu. Informasi yang sudah usang tidak akan mempunyai nilai lagi. Karena bila pengambilan keputusan terlambat, maka dapat berakibat fatal untuk organisasi. Kebutuhan akan tepat waktunya sebuah informasi itulah yang pada akhirnya akan menyebabkan mahalnya nilai suatu informasi.

Ketepatan waktu pelayanan berkaitan dengan waktu tunggu dan proses penyampaian informasi merupakan salah satu dimensi dalam meningkatkan kualitas pelayanan. Adanya pelayanan yang tepat waktu dapat meningkatkan kualitas pelayanan karena penerima informasi mandapatkan informasi yang diperlukan 
dengan cepat dan mudah. Maka semakin cepat dan tepat suatu informasi diberikan, semakin baik pula kualitas pelayanan yang diberikan.

H2: Terdapat pengaruh ketepatwaktuan (Timeliness) terhadap kualitas informasi pelayanan Bidang administrasi akademik di Sekolah Tinggi Multi Media Yogyakarta

\section{Faktor Kelengkapan Informasi (completeness) berpengaruh terhadap kualitas informasi pelayanan bidang akademik \\ Informasi yang dihasilkan atau} dibutuhkan harus memiliki kelengkapan yang baik, karena bila informasi yang dihasilkan sebagian-sebagian tentunya akan mempengaruhi dalam pengambilan keputusan atau menentukan tindakan secara keseluruhan, sehingga akan berpengaruh terhadap kemampuannya untuk mengontrol atau memecahkan suatu masalah yang terjadi dalam suatu organisasi tersebut.

Informasi dikatakan lengkap atau utuh bila dia tidak meninggalkan aspek-aspek penting yang melatarbelakangi suatu kejadian atau aktivitas yang diukur. Namun, informasi yang diberikan juga harus presisi dan tidak melebihi kemampuan pemrosesan pelanggan atau mungkin terlalu lengkap. Sistem informasi yang menghasilkan begitu banyak informasi juga dapat menyebabkan pelanggan tidak dapat memproses semuanya secara tepat waktu.

Kelengkapan informasi yang presisi secara langsung dapat mempengaruhi pengambilan keputusan penerima informasi dan juga dapat berpengaruh pada kualitas pelayanan yang diberikan. Kelengkapan informasi yang sesuai dan diberikan ke penerima informasi, maka pelayanan dapat dikatakan bermutu dan berkualitas sebalinya informasi yang kurang lengkap ataupun terlalu lengkap dapat menurunkan kualitas pelayanan informasi tersebut.

H3: Terdapat pengaruh kelengkapan informasi (Completeness) terhadap kualitas informasi pelayanan Bidang administrasi akademik di Sekolah Tinggi Multi Media Yogyakarta

Faktor Penyajian Informasi (format) berpengaruh terhadap kualitas informasi pelayanan bidang akademik

Informasi dikatakan dapat dipahami bila informasi disajikan dalam format yang berguna dan dapat dimengerti. Informasi dapat dimengerti oleh pengguna informasi karena dinyatakan dalam bentuk dan dengan istilah yang disesuaikan dengan batas pengertian atau pengetahuan pengguna informasi. Format informasi mengacu pada bagaimana informasi tersebut disajikan kepada pelanggan. Format yang sesuai untuk informasi tergantung pada pelanggan informasi dan penggunaan informasi. 
Penyajian informasi dapat memberikan pengaruh terhadap pengambil keputusan sehingga membuat adanya perbedaan dalam kualitas pelayanan yang dihasilkan. Penyajian informasi yang menggunakan tipe penyajian dan format yang baik dan menarik akan membuat kualitas pelayanan lebih tinggi jika dibandingkan dengan yang menggunakan tipe penyajian yang biasa dan kurang menarik. Hal tersebut menunjukkan bahwa format yang ada dalam penyampaian informasi sangatlah penting dalam meningkatkan kualitas pelayanan.

H4: Terdapat pengaruh penyajian informasi (Format) terhadap kualitas informasi pelayanan Bidang administrasi akademik di Sekolah Tinggi Multi Media Yogyakarta

H5: Terdapat faktor yang paling dominan berpengaruh terhadap kualitas informasi pelayanan Bidang administrasi akademik di Sekolah Tinggi Multi Media Yogyakarta

\section{METODE PENELITIAN}

Metode penelitian yang digunakan adalah penelitian penjelasan (explanatif) dengan studi khalayak, menurut Singarimbun dan Effendy (1995 : 65), penelitian penjelasan yang dimaksud untuk menyoroti hubungan antar variabel dan menguji hipotesis yang telah dirumuskan. Untuk mendukung penelitian ini, digunakan metode survey, yaitu penelitian yang mengambil sampel dari satu populasi dengan menggunakan kuesioner sebagai alat pengumpul data yang pokok.

Lokasi Penelitian adalah di Kampus Sekolah Tinggi Multi Media Yogyakarta tahun 2016.

Populasi dalam penelitian ini adalah para mahasiswa yang mengurus dan menerima jasa pelayanan di bagian akademik yang mengurus sesuatu jenis pelayanan di Sekolah tinggi Multi Media Yogyakarta. yang berjumlah 335 orang mahasiswa

Teknik pengambilan sampel menggunakan teknik Simple Random Sampling. Besarnya sampel yang diambil berdasarkan pada rumus sebagai berikut. Sampel ditentukan berdasarkan kriteria yang dibuat peneliti antara lain: mahasiswa bersedia menjadi responden, mahasiswa aktif tahun 2013/2014 masih menggunakan layanan akademis sehingga memahami perubahan kualitas informasi pelayanan akademik sampai tahun 2016.

$$
n=(Z)^{2} \frac{p \cdot q}{(S E)^{2}}
$$

(Arkin \& Colton dalam Suryatmoko, 2006:

3)

Dalam penelitian ini besarnya confidence interval ditentukan sebesar $95 \%$. Maka besarnya $\mathrm{Z}=1,96$ Sub-sub sampel ditentukan $\mathrm{p}: \mathrm{q}=0,5: 0,5$. Dan ditentukan $\mathrm{SE}= \pm 9,5 \%$. Maka : 


$$
n=(1,96)^{2} \frac{(0,5)(0,5)}{(0,095)^{2}}=106,41=106
$$

Jadi sampel yang diambil dalam penelitian ini adalah 106 orang.

Teknik pengumpulan data dalam penelitian ini menggunakan kuesioner.

Peneliti menyebar angket dan disertai alternatif jawaban dengan menggunakan skala Likert.

Table 1 variabel bebas sebagai faktor-faktor yang mempengaruhi kualitas informasi pelayanan bidang akademik

\begin{tabular}{|c|c|c|}
\hline No & Indikator & Komponen \\
\hline 1 & $\begin{array}{l}\text { Accuracy } \\
\text { keakuratan } \\
\text { informasi }\end{array}$ & $\begin{array}{l}\text { Data tepat dan akurat } \\
\text { Data sesuai degan kegiatan }\end{array}$ \\
\hline 2 & $\begin{array}{l}\text { Timeliness } \\
\text { ketepatwaktua } \\
\mathrm{n}\end{array}$ & $\begin{array}{l}\text { Penyampaian data tepat } \\
\text { waktu } \\
\text { Data yang disampaikan up to } \\
\text { date }\end{array}$ \\
\hline 3 & $\begin{array}{l}\text { Completeness } \\
\text { kelengkapan } \\
\text { informasi }\end{array}$ & $\begin{array}{l}\text { Data yang disajikan lengkap } \\
\text { Data yang disajikan sesuai } \\
\text { kebutuhan }\end{array}$ \\
\hline 4 & $\begin{array}{l}\text { Format } \\
\text { penyajian } \\
\text { informasi }\end{array}$ & $\begin{array}{l}\text { Informasi yang disajikan } \\
\text { mudah dibaca } \\
\text { Terdapat manual book }\end{array}$ \\
\hline
\end{tabular}

Tabel 2. Variabel terikat yaitu Kualitas Informasi:

\begin{tabular}{llll}
\hline No & Indikator & \multicolumn{3}{c}{ Komponen } \\
\hline 1 & Nilai & Manfaat (benefit) & \\
& & Biaya (cost) & \\
\hline 2 & Manfaat & Meningkatkan pemahaman & \\
& & Menghilangkan kegiatan yang & (nilai \\
& & tidak memiliki manfaat & \\
& & tambah) & \\
& & Meningkatkan lananan & dan \\
& & kepuasan pelanggan & \\
\hline 3 & Relevans & Mengurangi ketidakpastian, & \\
\hline
\end{tabular}

\begin{tabular}{llll}
\hline & i & $\begin{array}{l}\text { Memperbaki } \\
\text { pengambil keputusan, }\end{array}$ & \\
& & Sesuai dengan ekspetasi & \\
\hline $4 \quad$ Urgensi & $\begin{array}{l}\text { Prosedur pelaksanaan } \\
\text { pada software }\end{array}$ & perbaikan \\
& & Prosedur pelaksanaan \\
pada hardware & perbaikan \\
& & \\
\hline
\end{tabular}

Teknik analisis data menggunakan uji multikolinearitas, uji autokorelasi, dan uji heteroskedastisitas. Uji multikolinearitas dimaksudkan untuk menguji apakah model regresi ada korelasi antar variabel bebas, dengan memperhatikan nilai tolerance dan VIF (Variance Inflation Faktor). Sebagai prasyarat model regresi harus mempunyai nilai tolerance $>0,10$ dan nilai $\mathrm{VIF}<10$, maka tidak terjadi multikolinearitas (Ghozali, 2013 : 103).

Uji Autokorelasi dimaksudkan untuk menguji apakah antar residual terdapat korelasi yang tinggi. Uji statistik yang digunakan untuk mendeteksi autokorelasi adalah dengan Runs Tes. Apabila p value > 0,05 maka tidak terjadi autokorelasi (Ghozali, 2013:105).

Heteroskedastisitas bertujuan menguji apakah dalam model regresi terjadi ketidaksamaan variance dari residual satu pengamatan ke pengamatan yang lain tetap, maka disebut homoskedastisitas dan jika berbeda disebut heteroskedastisitas. Ada tidaknya heteroskedastisitas diketahui dengan melihat probabilitasnya terhadap derajat kepercayaan $5 \%$. Jika $p$ value $\geq$ 
0,05 maka tidak terjadi heteroskedastisitas (Ghozali, 2013:139).

Uji normalitas pada penelitian ini digunakan kolmogorov smirnov, jika $p$ value > 0,05, maka sebaran data dikatakan mendekati disitribusi normal atau normal (Ghozali, 2013: 160).

\section{Pengujian Hipotesis}

\section{Analisis Regresi Linier Berganda}

Analisis ini digunakan untuk mengetahui pengaruh dari faktor atau determinan kualitas informasi. Variabel bebas dalam penelitian ini merupakan faktor-faktor yang berpengaruh meliputi: faktor keakuratan informasi (accuracy), faktor ketepatwaktuan (timeliness), faktor kelengkapan informasi (completeness), dan faktor penyajian informasi (format). Variabel terikat dalam penelitian ini yaitu Kualitas Informasi Pelayanan Bidang Akademik. Rumus yang digunakan adalah :

$Y=a+b_{1} X_{1}+b_{2} X_{2}+b_{3} X_{3}+b_{4} X_{4}+e$

(Sugiyono, $2010: 178$ )

Keterangan :

$\mathrm{Y}=$ Kualitas Informasi Pelayanan

Bidang Akademik

$$
\begin{array}{ll}
\mathrm{a} & =\text { Konstanta } \\
\mathrm{X}_{1} & =\text { Keakuratan informasi (accuracy) } \\
\mathrm{X}_{2} & =\text { Ketepatwaktuan (timeliness) } \\
\mathrm{X}_{3} & =\text { Kelengkapan Informasi (completeness) } \\
\mathrm{X}_{4} & =\text { Penyajian Informasi (format) } \\
\mathrm{e} & =\text { Error } \\
\mathrm{b} & =\text { Koefisien regresi }
\end{array}
$$

Uji t. Analisis ini digunakan untuk membuktikan signifikansi pengaruh variabel bebas keakuratan informasi (accuracy), ketepatwaktuan (timeliness), kelengkapan informasi (completeness), penyajian informasi (format) secara parsial. Kritera keputusan dengan melihat $p$ value, maka dapat ditentukan apakah hipotesis nihil (Ho) ditolak atau diterima. Apabila $p$ value $\geq$ 0,05 maka Ho diterima dan Ha ditolak, artinya tidak ada pengaruh yang signifikan variabel bebas terhadap variabel terikat, sebaliknya apabila $p$ value $<0,05$ maka Ho ditolak dan Ha diterima, artinya ada pengaruh yang signifikan variabel bebas terhadap variabel terikat.

Uji F. Uji F digunakan untuk mengetahui pengaruh variabel bebas (keakuratan informasi (accuracy), ketepatwaktuan (timeliness), kelengkapan informasi (completeness), penyajian informasi (format) terhadap variabel terikat (kualitas informasi) secara bersama-sama. Kriteria pengujan apabila $p$ value $<0,05$ maka variable bebas berpengaruh terhadap variabel terikat secara bersama-sama.

\section{Koefisien Determinasi. Koefisien} determinasi $\left(\mathrm{R}^{2}\right)$ pada intinya mengukur seberapa besar sumbangan pengaruh variabel bebas (keakuratan informasi (accuracy), ketepatwaktuan (timeliness), kelengkapan informasi (completeness), penyajian informasi (format) dalam menerangkan variasi variabel terikat 
(kualitas informasi). Nilai koefisien determinasi adalah nol sampai dengan satu.

\section{HASIL DAN PEMBAHASAN}

Keakuratan Informasi (Accuracy) (X1)

\begin{tabular}{cccc}
\multicolumn{4}{c}{ Tabel 3.Distribusi Frekuensi Variabel } \\
Keakuratan & Informasi / Accuracy & X1) \\
\hline Nilai Interval & Kategori & $f$ & $\%$ \\
\hline Keakuratan & & & \\
Informasi & & & \\
$5-9$ & Sangat kurang & 1 & 0,9 \\
$10-14$ & Kurang & 15 & 14,2 \\
$15-19$ & Cukup Baik & 57 & 53,8 \\
$20-24$ & Baik & 33 & 31,1 \\
$\geq 25$ & Sangat baik & 0 & 0 \\
\hline
\end{tabular}

Sumber : Data primer diolah 2016

Berdasarkan Tabel 3 diketahui bahwa sebagian besar responden memiliki keakuratan informasi dengan kriteria cukup baik dengan interval15 - 19 sebesar 53,8\% dan keakuratan informasi dengan kategori sangat kurangsebesar $0,9 \%$.

\section{Ketepatwaktuan (Timeliness) (X2)}

Tabel 4.Distribusi Frekuensi Variabel Ketepatwaktuan (Timeliness) (X2)

\begin{tabular}{cccc}
\hline Nilai Interval & Kategori & $f$ & $\%$ \\
\hline Ketepatwaktuan & & & \\
$5-9$ & Sangat kurang & 2 & 1,9 \\
$10-14$ & Kurang & 36 & 34,0 \\
$15-19$ & Cukup Baik & 55 & 51,9 \\
$20-24$ & Baik & 13 & 12,3 \\
$\geq 25$ & Sangat baik & 0 & 0 \\
\hline
\end{tabular}

Sumber : Data primer diolah 2016

Berdasarkan Tabel 4. diketahui bahwa sebagian besar responden memiliki ketepatwaktuan dengan kriteria cukupbaik dengan nilai interval15 - 19 sebesar 51,9\% dan ketepatwaktuan dengan kategori sangat kurang sebesar $1,9 \%$.

\section{Kelengkapan Informasi (Completeness) (X3)}

Tabel 5 Distribusi Frekuensi Variabel

Kelengkapan Informasi (Completeness)

(X3)

\begin{tabular}{cccc}
\hline Nilai Interval & Kategori & $f$ & $\%$ \\
\hline Kelengkapan & & & \\
Informasi & & & \\
$5-9$ & Sangat kurang & 4 & 3,8 \\
$10-14$ & Kurang & 27 & 25,5 \\
$15-19$ & Cukup Baik & 54 & 50,9 \\
$20-24$ & Baik & 21 & 19,8 \\
$\geq 25$ & Sangat baik & 0 & 0 \\
\hline Sumber Data & primer diolah 2016 &
\end{tabular}

Sumber : Data primer diolah 2016

Berdasarkan Tabel 5 diketahui bahwa sebagian besar responden memiliki kelengkapan informasi dengan kriteria cukup baik dengan skor berkisar 15 - 19 sebesar 50,9\% dan kelengkapan informasidengan kategori sangat kurang sebesar $3,8 \%$.

\section{Penyajian Informasi (Format) (X4)}

Tabel 6 .Distribusi Frekuensi Variabel Penyajian Informasi (Format) (X4)

\begin{tabular}{cccc}
\hline Nilai Interval & Kategori & $f$ & $\%$ \\
\hline Kelengkapan & & & \\
Informasi & & & \\
$5-9$ & Sangat kurang & 3 & 2,8 \\
$10-14$ & Kurang & 24 & 22,6 \\
$15-19$ & Cukup Baik & 58 & 54,7 \\
$20-24$ & Baik & 21 & 19,8 \\
$\geq 25$ & Sangat baik & 0 & 0 \\
\hline
\end{tabular}

Sumber : Data primer diolah 2016

Berdasarkan Tabel 4.4 diketahui bahwa sebagian besar responden memiliki format informasi dengan kriteria cukup baik dengan skor berkisar 15 - 19 sebesar 54,7\% dan penyajian informasidengan kategori sangat kurang sebesar 2,8\%. 


\section{Kualitas Informasi Pelayanan Bidang}

\section{Akademik (Y)}

Tabel 7.Distribusi Frekuensi Variabel Kualitas Informasi Pelayanan Akademik (Y)

\begin{tabular}{cccc}
\hline Nilai Interval & Kategori & $f$ & $\%$ \\
\hline Kualitas & & & \\
Informasi & & & \\
Pelayanan & & & \\
Akademik & & & \\
$18-33$ & Sangat kurang & 2 & 1,9 \\
$34-49$ & Kurang & 11 & 10, \\
$50-65$ & Cukup Baik & 73 & 68,9 \\
$66-81$ & Baik & 20 & 18,9 \\
$\geq 85$ & Sangat baik & 0 & 0 \\
\hline
\end{tabular}

Sumber : Data primer diolah 2016

Berdasarkan tabel 7 diketahui bahwa sebagian besar responden memiliki kualitas informasi pelayanan akademikdengan kriteria cukup baik skor berkisar $50-65$ sebesar $68,9 \%$ dan kualitas informasi pelayanan akademikdengan kategori sangat kurang sebesar $1,9 \%$. 


\section{Diskritif Tabulasi Silang}

Tabel 8. Distribusi Frekuensi Tabulasi Silang Kualitas Informasi Pelayanan Akademik dengan Faktor-Faktor yang Mempengaruhi Kualitas Informasi Pelayanan Akademik

\begin{tabular}{|c|c|c|c|c|c|c|c|c|c|c|c|c|c|}
\hline & \multirow{3}{*}{ Variabel } & \multicolumn{12}{|c|}{ Kualitas Informasi Pelayanan Akademik (Y) } \\
\hline & & \multicolumn{2}{|c|}{$\begin{array}{c}\text { Sangat } \\
\text { Kurang }\end{array}$} & \multicolumn{2}{|c|}{ Kurang } & \multicolumn{2}{|c|}{ Cukup } & \multicolumn{2}{|c|}{ Baik } & \multicolumn{2}{|c|}{$\begin{array}{c}\text { Sangat } \\
\text { Baik }\end{array}$} & \multicolumn{2}{|c|}{ Total } \\
\hline & & $f$ & $\%$ & $f$ & $\%$ & $f$ & $\%$ & $f$ & $\%$ & $f$ & $\%$ & $f$ & $\%$ \\
\hline \multicolumn{14}{|c|}{ Keakuratan Informasi (Accu } \\
\hline & Sangat Kurang & 1 & 100 & 0 & 0,0 & 0 & 0,0 & 0 & 0,0 & 0 & 0,0 & 1 & 100 \\
\hline & Kurang & 0 & 0,0 & 6 & 40,0 & 9 & 60,0 & 0 & 0 & 0 & 0,0 & 15 & 100 \\
\hline & Cukup Baik & 1 & 1,8 & 3 & 5,3 & 42 & 73,7 & 11 & 19,3 & 0 & 0,0 & 57 & 100 \\
\hline & Baik & 0 & 0,0 & 2 & 6,1 & 22 & 66,7 & 9 & 27,3 & 0 & 0,0 & 33 & 100 \\
\hline & Sangat Baik & 0 & 0,0 & 0 & 0,0 & 0 & 0,0 & 0 & 0,0 & 0 & 0,0 & 0 & 0 \\
\hline \multicolumn{14}{|c|}{ 2) Ketepatwak } \\
\hline & Sangat Kurang & 1 & 50,0 & 0 & 0,0 & 1 & 50,0 & 0 & 0,0 & 0 & 0,0 & 2 & 100 \\
\hline & Kurang & 1 & 2,8 & 6 & 16,7 & 25 & 69,4 & 4 & 11,1 & 0 & 0,0 & 36 & 100 \\
\hline & Cukup Baik & 0 & 0,0 & 4 & 7,3 & 39 & 70,9 & 12 & 21,8 & 0 & 0,0 & 55 & 100 \\
\hline & Baik & 0 & 0,0 & 1 & 7,7 & 8 & 61,5 & 4 & 30,8 & 0 & 0,0 & 13 & 100 \\
\hline & Sangat Baik & 0 & 0,0 & 0 & 0,0 & 0 & 0,0 & 0 & 0,0 & 0 & 0,0 & 0 & 0 \\
\hline \multicolumn{14}{|c|}{ 3) Kelengkapa } \\
\hline & Sangat Kurang & 1 & 25,0 & 1 & 25,0 & 2 & 50,0 & 0 & 0,0 & 0 & 0,0 & 4 & 100 \\
\hline & Kurang & 0 & 0,0 & 6 & 22,2 & 20 & 74,1 & 1 & 3,7 & 0 & 0,0 & 27 & 100 \\
\hline & Cukup Baik & 1 & 1,9 & 3 & 5,6 & 40 & 74,1 & 10 & 18,5 & 0 & 0,0 & 54 & 100 \\
\hline & Baik & 0 & 0,0 & 1 & 4,8 & 11 & 52,4 & 9 & 42,9 & 0 & 0,0 & 21 & 100 \\
\hline & Sangat Baik & 0 & 0,0 & 0 & 0,0 & 0 & 0,0 & 0 & 0,0 & 0 & 0,0 & 21 & 100 \\
\hline \multicolumn{14}{|c|}{ 4) Penyajian Informasi (Format) (X4) } \\
\hline & Sangat Kurang & 1 & 33,3 & 0 & 0,0 & 1 & 33,3 & 1 & 33,3 & 0 & 0,0 & 3 & 100 \\
\hline & Kurang & 0 & 0,0 & 3 & 18,8 & 10 & 62,5 & 3 & 18,8 & 0 & 0,0 & 16 & 100 \\
\hline & Cukup & 0 & 0,0 & 1 & 3,6 & 20 & 71,4 & 6 & 21,4 & 1 & 3,6 & 28 & 100 \\
\hline & Baik & 1 & 2,6 & 2 & 5,3 & 20 & 52,6 & 15 & 39,5 & 0 & 0,0 & 38 & 100 \\
\hline & Sangat Baik & 0 & 0,0 & 1 & 4,8 & 6 & 28,6 & 13 & 61,9 & 1 & 4,8 & 21 & 100 \\
\hline
\end{tabular}

Sumber: data primer diolah, 2016

\section{Uji Asumsi Klasik}

Uji Normalitas

Tabel 4.7. Hasil Uji Normalitas

\begin{tabular}{lccc}
\hline \multicolumn{1}{c}{ Variabel } & KSZ & Sig. & Keterangan \\
\hline Unstandardized & & 0,473 & \\
Residual & 0,845 & & Normal
\end{tabular}

Sumber: data primer diolah, 2016

$$
\text { Berdasarkan tabel di atas dapat }
$$

diketahui bahwa nilai Kolmogorov-Smirnov pada variabel unstandardized residual, dengan nilai signifikansi lebih besar dari 0,05 sehingga dapat dikatakan berdistribusi normal.

\section{Uji Multikolinieritas}

Tabel 4.8. Hasil Uji Multikolinieritas

\begin{tabular}{lccc}
\hline \multicolumn{1}{c}{ Variabel } & Tolerance & VIF & Kesimpulan \\
\hline $\begin{array}{l}\text { Keakuratan } \\
\text { Informasi } \\
\text { Accuracy) (X1) }\end{array}$ & 0,828 & 1,208 & $\begin{array}{c}\text { No } \\
\text { multikolinieritas }\end{array}$ \\
$\begin{array}{l}\text { Ketepatwaktuan } \\
\text { (Timeliness) }\end{array}$ & 0,835 & 1,198 & $\begin{array}{c}\text { No } \\
\text { multikolinieritas }\end{array}$ \\
$\begin{array}{l}\text { Kelengkapan } \\
\text { Informasi } \\
\text { (Completeness) }\end{array}$ & 0,821 & 1,218 & $\begin{array}{c}\text { No } \\
\text { multikolinieritas }\end{array}$ \\
$\begin{array}{l}\text { Penyajian } \\
\text { Informasi } \\
\text { (Format) (X4) }\end{array}$ & 0,875 & 1,143 & \begin{tabular}{c} 
Multikolinieritas \\
\hline
\end{tabular} \\
\hline
\end{tabular}

Sumber: Data primer diolah 2016 
Hasil uji multikolineritas masingmasing variabel independen diperoleh Tolerance $>0,1$ dan nilai $V I F<10$ nilai maka dapat disimpulkan bahwa tidak terjadi gejala multikolinearitas

\section{Uji Autokorelasi}

Hasil analisis diketahui nilai Durbin-Watson sebesar 1,761yang berada di antara nilai du sebesar 1,762 dan 4-du sebesar 2,238 sehingga dikatakan dalam model tidak ada autokorelasi.

\section{Uji Heteroskedastisitas}

Tabel 4.9. Hasil Uji Heteroskedastisitas

\begin{tabular}{lccc}
\hline \multicolumn{1}{c}{ Variabel } & Beta & $T_{\text {hitung }}$ & Sig. \\
\hline $\begin{array}{l}\text { Keakuratan Informasi } \\
\text { (Accuracy) (X1) }\end{array}$ & 0,013 & 0,089 & 0,930 \\
$\begin{array}{l}\text { Ketepatwaktuan } \\
\text { (Timeliness) (X2) }\end{array}$ & $-0,212$ & - & 0,126 \\
Kelengkapan Informasi & 0,058 & 0,396 & 0,693 \\
\hline
\end{tabular}

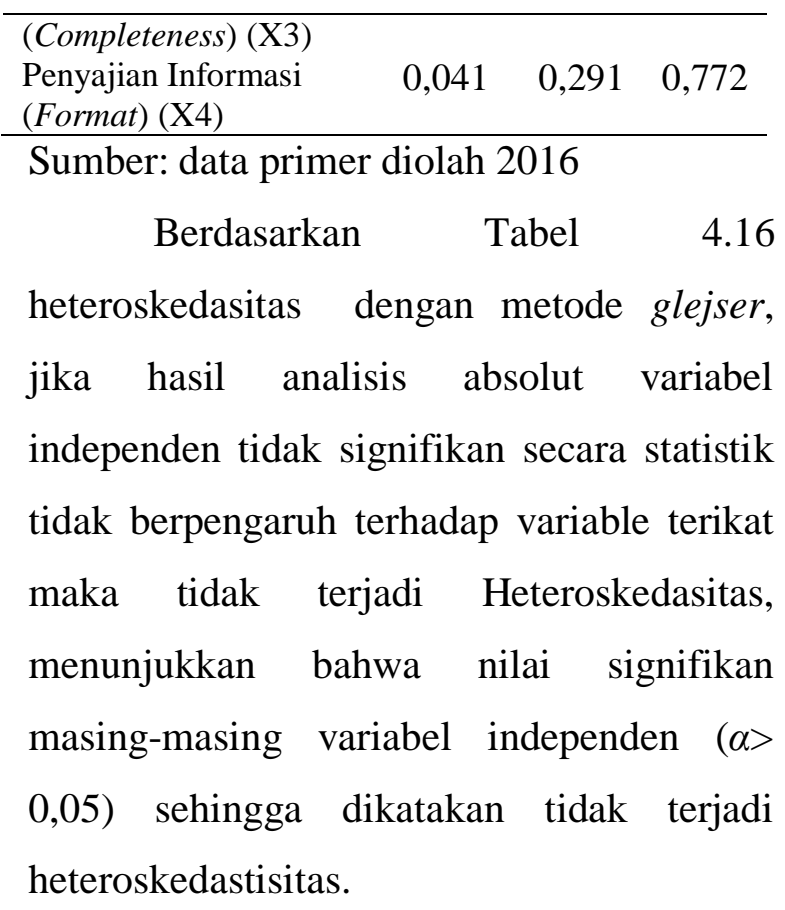

Tabel 4.10. Hasil Uji Regresi Linear Berganda

\begin{tabular}{lcccrr}
\hline \multicolumn{1}{c}{ Variabel } & Koefisien & t hit & Sig. t & SE \% & SR\% \\
\hline Keakuratan Informasi (Accuracy) (X1) & 0,943 & 3,790 & $0,000^{*}$ & 14,9 & 38,6 \\
Ketepatwaktuan (Timeliness) (X2) & 0,504 & 2,066 & $0,041^{*}$ & 6,8 & 17,7 \\
Kelengkapan Informasi (Completeness) (X3) & 0,534 & 2,379 & $0,019^{*}$ & 8,5 & 22,0 \\
Penyajian Informasi (Format) (X4) & 0,624 & 2,827 & $0,006^{*}$ & 8,3 & 21,6 \\
Konstanta & & 13,616 & & & \\
F $_{\text {hitung }}$ & & 15,812 & & \\
Sig. F & & $0,000^{*}$ & & \\
$R$ Square & 0,385 & & \\
\end{tabular}


Hasil analisis regresi berganda diatas dapat diperoleh persamaan regresi sebagai berikut:

\section{Pembahasan Hasil Penelitian}

Pengaruh Faktor Keakuratan Informasi (Accuracy) Terhadap Kualitas Informasi Pelayanan Bidang administrasi akademik di Sekolah Tinggi Multi Media Yogyakarta.

Faktor accuracy terbukti berpengaruh secara signifikan terhadap kualitas informasi pelayanan bidang administrasi. Hal ini dapat diartikan, bahwa jika keakuratan informasi / Accuracy meningkat, maka kualitas informasiakan mengalami peningkatan. Tingkat keakuratan informasi yang disajikan pihak bidang adminisrasi akademik merupakan hal yang sangat penting dan dapat mempengaruhi keakuratan informasi yang disajikan pelayanan bidang administrasi akademik.

Hasil penelitian ini sesuai dengan penelitian yang dilakukan oleh Sudarmadi (2010) yang mengatakan bahwa persepsi kualitas informasi berpengaruh signifikan terhadap kepuasan pengguna sistem informasi. Informasi yang akurat merupakan syarat bahwa informasi tersebut telah memiliki kualitas informasi yang baik. Sedangkan kualitas informasi yang baik akan memberikan kepuasan bagi pengguna sistem informasi tersebut.
Kualitas informasi pelayanan harus didukung oleh keakuratan informasi yang disajikan. Keakuratan informasi yang disediakan adalah penilaian bahwa sumber informasi menyediakan informasi yang akurat. Kebenaran informasinya dapat dipercaya adalah penilaian bahwa sumber informasi tersebut memberikan informasi yang dapat dipercaya tingkat kebenarannya.

Komponen ketepatan dan keakuratan informasi sebagian besar responen menjawab netral sehingga memberikan gambaran kencenderungan pada kategori cukup baik. Komponen kesesuaian kegiatan diketahui sebagian besar responden menjawab setuju. Dengan demikian semua kegiatan yang dilaksanakan sudah sesuai.

Mulyanto (2009) menjelaskan bahwa Informasi yang akurat harus memiliki kelengkapan yang baik, karena bila informasi yang dihasilkan sebagian tentunya akan mempengaruhi dalam pengambilan keputusan atau menentukan tindakan secara keseluruhan, sehingga akan berpengaruh terhadap kemampuannya untuk mengontrol atau memecahkan suatu masalah dengan baik.

Berdasarkan hasil penelitian, teori dan penelitian sebelumnya dapat dinyatakan bahwa Accuracy berpengaruh secara signifikan terhadap kualitas informasi pelayanan bidang administrasidi Sekolah Tinggi Multi Media Yogyakarta. Keakuratan informasi memiliki peranan yang sangat 
penting dalam meningkatkan kualitas informasi. Pelayanan bidang administrasi harus menyampaikan suatu informasi yang akurat, benar dan dapat dipertanggung jawabankan kebenarannyaagar tidak menimbulkan kesalahfahaman yang dapat menimbulkan gangguan ataupun masalah dikemudian hari.

\section{Pengaruh Ketepatwaktuan (timeliness) Terhadap Kualitas Informasi Pelayanan Bidang administrasi akademik di Sekolah Tinggi Multi Media Yogyakarta.}

Faktor timeliness berpengaruh positif dan signifikan terhadap kualitas informasi. Hal ini dapat diartikan, bahwa jika timeliness meningkat, maka kualitas informasiakan mengalami peningkatan. Tingkat ketepatwaktuan sebuah informasi merupakan hal yang sangat penting dapat mempengaruhi kualitas informasi yang disajikan oleh pelayanan bidang administrasi.

Hasil penelitian tersebut mendukung penelitian yang dilakukan oleh Santika Amesti Aditya (2014) yang menunjukkan bahwa terdapat pengaruh yang positif antara tepat waktu terhadap Kualitas Informasi. Informasi dikatakan tepat waktu bila informasi tersedia pada waktu para pengambil keputusan menggunakannya untuk membuat keputusan. Informasi harus disampaikan secepat mungkin agar dapat digunakan sebagai dasar untuk membantu dalam pengambilan keputusa-keputusan perusahaan dan untuk menghindari tertundanya pengambilan keputusan. Informasi datang ke penerima tidak boleh terlambat karena umur informasi merupakan faktor yang kritikal dalam menentukan kegunaannya.

\section{Faktor ketepatwaktuan / timeliness} berdasarkan jawaban responden diketahui sebagian besar memperoleh informasi yang tepat waktu dengan kategori cukup, dengan adanya penyajian informasi yang cukup maka kualitas seuatu informasi dinyatakan kurang maksimal, untuk itu adaya ketepatwaktuan dalam menyampaikan sebuah informasi harus diperbaiki lagi. Menurut sebaran jawaban responden secara empiris lebih besar dibandingkan skor hipotesis hasil tersebut dapat diartikan bahwa sebaran jawaban responden cenderung positif.

Komponen penyampaian data tepat waktu sebagian besar responen sehingga memberikan gambaran hasil presentasi dengan kategori cukup baik. Berdasarkan dimensi data yang disampaikan up to date artinya semua informasi harus selalu di up date menjadi yang terbaru, sehingga informasi tersebut tidak usang. Upaya yang harus dilakukan untuk meningkatkan kualitas pelayanan pada dimensi timeliness yaitu pelayanan yang diberikan harus cepat dan tepat.

\section{Makhbub Zunaedi} (2011) menyatakan bahwa ketepatan adalah kegiatan menyajikan informasi pada saat 
transaksi terjadi atau pada saat informasi tersebut dibutuhkan, sehingga mampu menutup peluang bagi pesaing untuk mengambil keputusan yang baik dan lebih cepat.

Berdasarkan hasil penelitian, teori dan penelitian sebelumnya dapat dinyatakan bahwa ketepatan waktu / timeliness berpengaruh positif dan signifikan terhadap kualitas informasipelayanan bidang administrasidi Sekolah Tinggi Multi Media Yogyakarta.Pentingnya ketepatan waktu informasi harus ditingkatkan kembali oleh pelayanan bidang administrasi di sekolah karena berpengaruh terhadap pengambilan keputusan setiap orang yang menerima informasi tersebut. Sehingga semakin tinggi ketepatan waktu dalam menyediakan informasi maka akan semakin berkualitas sebuah informasi. Sehingga pihak bagian administrasi diharuskan dapat meningkatkan ketepatwaktuan dalam menyampaikan informasi kepada mahasiswa, salah satu caranya yang dapat dilakukan dengan memutuskan sebuah informasi dan memberikan informasi langsung kepada mahasiswa tanpa menunggu lama.

\section{Pengaruh Kelengkapan Informasi (Completeness) Terhadap Kualitas Informasi Pelayanan Bidang administrasi akademik di Sekolah Tinggi Multi Media Yogyakarta}

Faktor kelengkapan informasi completeness secara signifikan terbukti berpengaruh terhadap kualitas informasi pelayanan Bidang administrasi.Hal ini dapat diartikan, bahwa jika kelengkapan informasi I completeness meningkat maka kualias informasi akan mengalami peningkatan. Tingkat kelengkapan informasi merupakan hal yang sangat penting yang dapat mempengaruhi kualitas informasi yang disajikan oleh pelayanan bidang administrasi akademik.

Hasil penelitian tersebut didukung oleh penelitian yang dilakukan oleh Santika Amesti Aditya (2014), yang menunjukkan bahwa terdapat pengaruh antara informasi yang complete terhadap kualitas informasi akuntansi pada RSUD Ungaran. Informasi yang disajikan secara lengkap akan memberikan nilai manfaat yang dapat mempengaruhi sikap dan pengambilan keputusan setiap pihak yang menerima informasi tersebut. Untuk itu adanya informasi yang lengkap akan memberikan kepuasan tersediri bagi pengguna informasi.

Komponen kelengkapan informasi sebagian besar responden menjawab dengan kategori cukup baik. Kelengkapan Informasi harus ditingkatkan agar dapat meningkatkan kualitas dari suatu informasi. Upaya yang perlu dilakukan pihak pelayanan untuk meningkatkan completeness yaitu informasi harus disajikan dengan tingkat kualitas bahasa dan susunan yang mudah difahami, informasi yang dihasilkan harus ditindak lanjuti terlebih dahulu agar terbukti kebenaran dan disampaikan dengan detail, 
selain itu informasi juga harus difahami lebih detail oleh pegawai bagian pelayanan administrasi agar mereka dapat menjelaskan dengan tepat ketika terdapat beberapa mahasiswa yang tidak faham dalam menerima informasi dan meminta penjelasan lebih lanjut dari pihak pelayanan. Komponen kesesuaian kegiatan diketahui sebagian besar responden menjawab sangat setuju.Dengan demikian semua kegiatan yang dilaksanakan sudah sesuai.

Berdasarkan hasil penelitian, teori dan penelitian sebelumnya dapat dinyatakan bahwa Kelengkapan informasi / completeness berpengaruh signifikan terhadap kualitas informasi pelayanan bidang administrasi akademik di Sekolah Tinggi Multi Media Yogyakarta. Hal tersebut menunjukkan bahwa pelayanan informasi bidang administrasi yang menyajikan sebuah informasi dengan lengkap sangat berpengaruh penting dalam meningkatkan kualitas informasi. Pelayanan bidang administrasi harus dapat menyampaikan informasi secara detail agar dapat memberikan gambaran yang pasti pada pembaca informasi.

Pengaruh Penyajian Informasi (Format) Terhadap Kualitas Informasi Pelayanan Bidang administrasi akademik di Sekolah Tinggi Multi Media Yogyakarta

Penyajian informasi berpengaruh signifikan terhadap kualitas informasi pelayanan bidang administrasi.Hasil tersebut dapat diartikan jika penyajian informasi / Format naik maka kualitas informasi akan mengalami peningkatan. Hasil tersebut mengindikasikan bahwa penyajian informasi merupakan hal yang penting dan dapat mempengaruhi kualitas suatu informasi yang disajikan oleh pelayanan bidang administrasi akademik.

Penyajian informasi yang disajikan bidang administrasi tidak lepas dari kompetensi dan kemampuan sumber daya manusia yang bekerja di bidang administrasi dalam mengolah, membuat dan memformat bentuk maupun tatanan sebuah informasi untuk disampaikan kepada mahasiswa. Kompetensi merupakan suatu karakteristik dari seseorang yang memiliki keterampilan (skill), pengetahuan (knowledge), dan kemampuan (ability) untuk melaksanakan suatu pekerjaan. Menurut beberapa pakar, kompetensi adalah karakteristik yang mendasari seseorang mencapai kinerja yang tinggi dalam pekerjaannya. Pegawai yang tidak mempunyai pengetahuan yang cukup akan bekerja tersendat-sendat dan juga mengakibatkan pemborosan bahan, waktu, dan tenaga (As Syifa, 2014).

Penyajian informasi diketahui sebagian besar dengan presentase cukup baik. Penyajian informasi / format perlu ditingkatkan agar dapat meningkatkan kualitas informasi tersebut. Adapun upaya yang harus dilakukan untuk meningkatkan format yaitu adanya pembelajaran dan 
bimbingan lebih lanjut terhadap sumber daya manusia yang bekerja pada pelayanan administrasi agar dapat membuat dan menyajikan suatu informasi yang lebih menarik.

Berdasarkan hasil penelitian, teori dan penelitian sebelumnya dapat dinyatakan bahwa penyajian informasi berpengaruh secara signifikan terhadap kualitas informasi pelayanan bidang administrasi akademik di Sekolah Tinggi Multi Media Yogyakarta. Penyajia informasi memiliki peranan yang sangat penting dalam meningkatkan kualitas informasi.Sehingga pihak pelayanan harus membuat suatu informasi dengan lebih baik lagi agar dapat meningkatkan minat baca para mahasiswa untuk memperoleh informasi yang baik dan positif bagi kebutuhan bersama.

\section{Pengaruh Keakuratan Informasi, Ketepatan Waktu, Kelengkapan Informasi, dan Penyajian Informasi secara bersama-sama terhadap Kualitas Informasi Pelayanan Bidang administrasi akademik di Sekolah Tinggi Multi Media Yogyakarta}

Keakuratan informasi, ketepatan waktu, kelengkapan informasi, dan penyajian informasi secara bersama-sama berpengaruh signifikanterhadap Kualitas Informasi Pelayanan Bidang administrasi akademik di Sekolah Tinggi Multi Media Yogyakarta. Hal ini berarti untuk meningkatkan kualitas informasi pada Bidang administrasi akademik di Sekolah Tinggi Multi Media
Yogyakartadapat dilihat berdasarkan Keakuratan informasi, ketepatan waktu, kelengkapan informasi dan penyajian informasi secara keseluruhan dengan kontribusi sebesar 38,5\%.Variabel keakuratan informasi merupakan variabel yang paling dominan berpengaruh terhadap kualitas informasi pada pelayanan bidang administrasi akademik di Sekolah Tinggi Multi Media Yogyakarta, selanjutnya variabel penyajian informasi, variabel kelengkapan informasi dan variabel ketepatan waktu.

Kualitas informasi pelayanan akademik dapat dipengaruhi beberapa faktor melliputi antara lain : keakuratan informasi (accuracy), ketepatwaktuan (timeliness), kelengkapan informasi (completeness) dan penyajian informasi (format). Keempat aspek ini memiliki peran yang besar terhadap kualitas informasi yang diberikan oleh bidang administrasi akademik. Berdasarkan hasil penelitian diketahui bahwa variabel keakuratan informasi (accuracy), ketepatwaktuan (timeliness), kelengkapan informasi (completeness) dan penyajian informasi (format) berpengaruh secara positif dan signifikan terhadap Kualitas Informasi Pelayanan Bidang administrasi akademik di Sekolah Tinggi Multi Media Yogyakarta.

Menurut Prof. Robert Craig dari tujuh tradisi teori komunikasi dalam pembahasan ini, mengacu pada tradisi Sibernetika komunikasi sebagai pengolah 
informasi. Teori ini memandang komunikasi sebagai suatu sistem dimana berbagai elemen yang terdapat di dalamnya saling berinteraksi dan saling mempengaruhi satu sama lain. Dalam hal ini komunikasi sebagai proses informasi dan masalah yang banyak dihubungkan dengan keramaian, kelebihan beban, dan malfungsi. Tradisi ini berkaitan dengan proses pembuatan keputusan. Sistem ini bersifat terbuka, sehingga perkembangan dan dinamika yang terjadi di lingkungan akan diproses didalam internal sistem. Sibernetika digunakan dalam topik-topik tentang diri individu, percakapan, hubungan interpersonal, kelompok, organisasi, media, budaya dan masyarakat. Dalam sibernetika, komunikasi dipahami sebagai sistem bagianbagian atau variabel-variabel yang saling mempengaruhi satu sama lain, membentuk serta mengontrol karakter keseluruhan sistem dan layaknya organisme menerima keseimbangan dan perubahan (Little John, 2009).

Penelitian yang dilakukan oleh Makhbub Zunaedi, dkk (2011) menunjukkan bahwa variabel akurasi, ketepatan waktu dan relevansi secara bersama-sama (simultan) berpengaruh signifikan terhadap kepuasan pemakai sistem informasi ATEMIS on Web di PT. TELKOM MSC area IV Jawa Tengah dan DIY.Selain itu penelitian yang dilakukan Gita Gowinda Kirana (2010) dalam penelitiannya terhadap penggunaan E-filling di kota Semarang, dengan menggunakan model kesuksesan sistem informasi DeLone \& McLean membuktikan bahwa kualitas informasi mempunyai pengaruh positif terhadap kepuasan user. Jika informasi yang dihasilkan lengkap, relevan, akurat, tepat waktu dan disajikan secara jelas, maka pengguna akan merasa puas. Kepuasan pelanggan tersebut merupakan aspek pemenuhan suatu informasi yang berkualitas.

Berdasarkan hasil penelitian, teori dan penelitian sebelumnya dapat dinyatakan bahwa keakuratan informasi (accuracy), ketepatwaktuan (timeliness), kelengkapan informasi (completeness) dan penyajian informasi (format) berpengaruh signifikan terhadap Kualitas Informasi Pelayanan Bidang administrasi akademik di Sekolah Tinggi Multi Media Yogyakarta. Hal tersebut menunjukkan bahwa proses Kualitas Informasi Pelayanan dapat dilakukan secara maksimal jika universitas juga mempertimbangkan faktor-faktor yang mempengaruhinya. Secara keseluruhan bahwa faktor-faktor tersebut secara bersamasama berpengaruh terhadap Kualitas Informasi Pelayanan Bidang administrasi akademik di Sekolah Tinggi Multi Media Yogyakarta degan nilai signifikan.

\section{SIMPULAN}

1. Faktor keakuratan informasi (Accuracy) berpengaruh positif dan signifikan terhadap kualitas informasi pelayanan 
Bidang administrasi akademik di Sekolah Tinggi Multi Media Yogyakarta.

2. Faktor ketepatanwaktu (Timeliness) berpengaruh positif dan signifikan terhadap kualitas informasi pelayanan Bidang administrasi akademik di Sekolah Tinggi Multi Media Yogyakarta.

3. Faktor completeness berpengaruh positif dan signifikan terhadap kualitas informasi pelayanan Bidang administrasi akademik di Sekolah Tinggi Multi Media Yogyakarta.

4. Faktor format berpengaruh positif dan signifikan terhadap kualitas informasi pelayanan Bidang administrasi akademik di Sekolah Tinggi Multi Media Yogyakarta.

5. Faktor accuracy, timeliness, completeness dan format secara bersamasama berpengaruh signifikan terhadap kualitas informasi pelayanan bidang akademik dengan kontribusi sebesar $38,5 \%$ dan sisanya $61,5 \%$ dipengaruhi oleh faktor lain yang tidak diteliti dalam penelitian ini. Faktor yang paling dominan terhadap kualitas informasi pelayanan yaitu faktor accuracy.

\section{Keterbatasan}

Penelitian ini terdapat keterbatasan sehingga penelitian ini hanya menguji empat variabel antara lain variabel keakuratan informasi, ketepatan waktu, kelengkapan informasi, dan penyajian informasi. Ada beberapa faktor yang dimungkinkan dapat berpengaruh terhadap kualitas sumber informasi selain dari faktor yang dijadikan variabel bebas seperti Kualitas SDM, kompetensi, profesional dan peran managemen.

\section{DAFTAR PUSTAKA}

Sadat, 2000, Analisis Hubungan Kinerja Jasa Perguruan Tinggi terhadap Kepuasan Mahasiswa: Studi Kasus Universitas Indonesia, Tesis, Jakarta: Pascasarjana Universitas Indonesia, hlm. 1

Asih, Daru, 2012, Analisis Faktor Kualitas Layanan Administrasi Akademik dalam Memberikan Kepuasam Kepada Mahasiswa di Fakultas Ekonomi dan Bisnis UniversitasMercu-Buana-Jakarta.

Jurnal http://eprints.unisbank.ac.id/189/1/ar tikel-25.pdf

Delone, W.H. \& McLean, E. R. (2003). The DeLone and McLean model of information systems success: a tenyear update. Journal of Management Information Systems 19(4), 9-30.

Kadir, Abdul. 2003, Pengenalan Sistem Informasi, Yogyakarta: Andi, hlm. 35 Amsyah, Zulkifli. 2001, Manajemen Sistem Informasi. Jakarta: Gramedia Pustaka Utama.

Singarimbun dan Effendy, 1995, Metode Penelitian Survey, Jakarta, LP3ES, hlm. 65

Ghozali, Imam. 2013. Aplikasi Analisis Multivariate dengan program SPSS, Badan Penerbit Universitas Diponegoro, Semarang, hlm. 47, 52, 103

Sudarmadi, 2010, Faktor-faktor Yang Mempengaruhi Kepuasan Pengguna Sistem Informasi. Tesis. Univeritas 
Sebelas Maret Surakarta Amesti Aditya (2014)

Makhbub Zunaedi, 2011, Analisis Pengaruh

Akurasi, Ketepatan Waktu Dan

Relevansi Informasi Terhadap Kepuasan Pemakai Sistem Informasi Atemis On Web Di Pt.Telkom Msc Area IV Jawa Tengah Dan DIY. Seminar Nasional Teknologi Informasi \& Komunikasi Terapan 2011 (Semantik 2011) ISBN 979-260255-0.

As Syifa, 2014, Pengaruh Kompetensi Sumber Daya Manusia, Penerapan Sistem Akuntansi Keuangan Daerah (Sakd), Pemanfaatan Teknologi Informasi, Dan Sistem Pengendalian Intern Terhadap Kualitas Laporan Keuangan Pemerintah Daerah (Studi Empiris Pada SKPD Kota Depok). Jurnal: Universitas Diponegoro Semarang.

Littlejohn Stephen W \& Karen A. Foss, 2011, Theories of Human Communication, tenth edition, Waveland Press, Inc,USA : hlm.5152

Gita Gowinda Kirana, 2010, Analisis

Perilaku Penerimaan Wajib Pajak Terhadap Penggunaan E-Filling. Jurnal: Fakultas Ekonomi Universitas Diponegoro Semarang 